\title{
A KLEPTOPARASITIC CECIDOMYIID AND OTHER FLIES ASSOCIATED WITH SPIDERS
}

\author{
By John Sivinski ${ }^{1}$ AND Mark Stowe ${ }^{2}$
}

Spiders and their webs are predictable sources of insect cadavers. A small number of animals regularly exploit this resource, either as kleptoparasites or commensals, depending on whether symbionts compete for the same prey (see Robinson and Robinson, 1977, for more detailed terminology). Among the thieves are specialized spiders (citations in Vollrath 1979a, 1979b), mature male and juvenile spiders (Stowe 1978, citations in Nyffeler and Benz 1980), Hemiptera (Davis and Russell 1969), a hummingbird (takes webbing in addition to small insects, Young 1971), panorpid scorpionflies (Thornhill 1975), Lepidoptera larvae (Robinson 1978), wasps (Jeanne 1972), damselflies (Vollrath 1977), and a handful of flies (reviews in Knab 1915; Bristowe 1931, 1941; Lindner 1937; Richards 1953; Robinson and Robinson 1977). Only a few of the reports on Diptera kleptoparasites originate from North America (McCook 1889, Frost 1913, Downes and Smith 1969). With a single exception (Downes and Smith 1969), all of the previously described kleptoparasitic flies belong to the Brachycera and Cyclorrhapha. We report here on a surprisingly diverse kleptoparasitic Diptera fauna in north central Florida with a cecidomyiid (Nematocera) as its dominant member.

\section{METHODS}

Unless otherwise noted, specimens were taken in Alachua County, Florida, during August and September, 1980. Observations were made principally at night, using red filtered light. A trap was constructed to test whether flies were attracted to dead insects in general or those partially digested by spiders in particular. Transparent plastic discs $(10 \mathrm{~cm}$. dia.) were covered on one side with Tacky Trap ${ }^{\circledR}$, a trapping compound. Three discs were strung between bamboo poles and placed near a web of Nephila clavipes (a

\footnotetext{
${ }^{1}$ Department of Entomology and Nematology, University of Florida, Gainesville, Fla. 32611

${ }^{2}$ Museum of Comparative Zoology, Harvard University, Cambridge, Mass. 02138 Manuscript received by the editor May 13, 1981.
} 
large orb-web spider). On one disc was placed a cricket (Gryllus assimilis) that had been fed on by the spider for 30-60 minutes. Another carried an intact cricket, killed by freezing, then thawed, and the third was a blank control. Fourteen replicates were made. In addition, we periodically collected by aspiration flies hanging on webs and spider draglines independent of webs.

\section{RESULTS}

We propose various flies to be spider symbionts on the basis of either direct or circumstantial evidence. The latter category consists of flies caught exclusively, or for the most part, on trap discs baited with partially consumed spider prey.

\section{Known Kleptoparasites}

Cecidomyiidae: Didactylomyia longimana (Felt), length $1.3 \mathrm{~mm}$. This most abundant of kleptoparasites was active at dusk and night. In certain locations virtually every Nephila clavipes with prey would have from one to over a dozen midges perched on the semi-digested prey (Fig. 1). We also observed D. longimana in association with other araneids; Argiope aurantia, Mastophora bisaccata, and Eriophora ravilla. While individuals were sometimes found on swathed insects stored in the web, they were more commonly seen on fluid-covered prey being consumed by the spider. Midges were observed with their heads applied to the surface of the insect and their abdomens expanded, leaving no doubt that feeding had occurred. Rarely, a fly was found on the dorsal surface of the abdomen or the carapace of a spider. Examination of $3 \times$ photographs of flies resting on spiders shows no evidence of feeding on the spider. Spiders defended their catch from $D$. longimana by batting at approaching flies with their forelegs. One of us (Stowe) has seen Scoloderus cordatus (Araneidae) vigorously brushing nematocerous flies off its prey. McCook (1889) describes a similar behavior in Argiope aurantia. Since Nephila, Argiope, and Scoloderus are in separate subfamilies, the behavior may predate the radiation of the family. (Nephila maculata behaves similarly toward kleptoparasitic spiders of the genus Argyrodes, Robinson and Robinson, 1973; however in Scoloderus this behavior must be adapted for kleptoparasitic flies alone since Argyrodes are never in their webs.) Prey defense is indicative of a competitive relationship and substantiates 

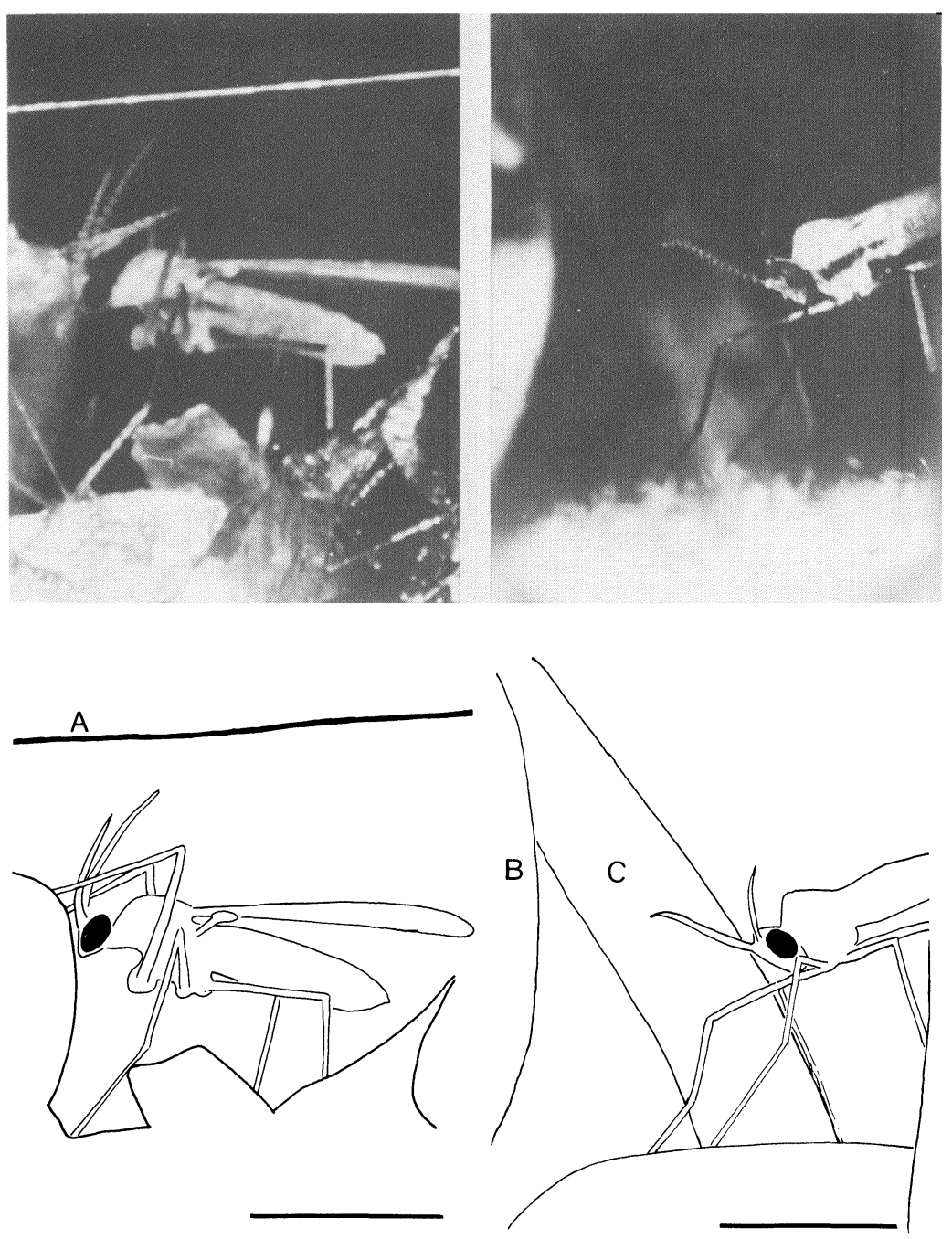

Figure 1. (left) A female Didactylomyia longimana perched on the partially consumed prey of Nephila clavipes; (right) D. longimana female on the cephalothorax of Argiope aurantia. A) line in Nephila web; B) anterior end of abdomen; C) leg (space bars $1 \mathrm{~mm}$ ). 
our classification of the midge as a kleptoparasite rather than a commensal.

True carnivory, the direct consumption of animal food, is unknown among adult cecidomyiids. The only previous record of kleptoparasitism and protein consumption we are aware of concerns two African species that steal regurgitants being passed between ants (Farquharson 1922). A record of cecidomyiids attached to the wings of Neuroptera is probably a misidentification of a ceratopogonid ectoparasite (described by Slosson 1896).

Twenty flies were aspirated from spider prey; all were females. Traps baited with partially digested insects captured 7 females. No midges were taken on the trap with a dead, intact insect or on the control. The flies are probably attracted by volatile products of the spider's external digestion. Flies always approached from downwind and were often seen attempting to land on the spiders' mouthparts just after a feeding bout.

Milichiidae (acalypterate Cyclorrhapha): The Milichiidae contain a number of kleptoparasitic species, primarily in the genera Desmometopa, Phyllomyza, and Neophyllomyza. Hosts include asilid flies (Kertesz 1897; Mik 1898; Biro 1899; Peyerimhoff 1917), reduviid bugs (Biro 1899; Richards 1953; Robinson 1977), and crab, orb-web, and jumping spiders (Frost 1913; Richards 1953). The spider Misumena vatia strikes out at approaching milichiids and oscillates to dislodge those already perched on prey (Biro 1899). Again, defense suggests competition, hence, kleptoparasitism.

Paramyia nitens (Loew), length $1.9 \mathrm{~mm}$. This small black fly was seen on two occasions: a single individual was found on the prey of a Nephila clavipes and approximately 10 flies on a vespid wasp being consumed by an $A$. aurantia. Both observations were at night. The fly is agile and difficult to dislodge from prey. One individual managed to balance on the spider's prey while the prey item was briskly rotated beneath the chelicerae of its host (behavior and appearance are similar to that of an unidentified fly watched by McCook 1889). All 5 specimens captured were females. The mouthparts of milichiids are often elongated; those of Paramyia nitens are strikingly exaggerated, nearly as long as the body. The rostrum alone is $1.3 \times$ the height of the head. This extension may aid in reaching through wrapping silk or lapping at the particularly fluid, but dangerous, areas near the spider's mouthparts. Such precarious feeding, apparently between the jaws of spiders, has been 
noted in Didactylomyia longimana; unidentified fly (McCook 1889); and milichiids, (Champion-Jones 1937; Robinson and Robinson 1977). The mouthparts of $D$. longimana are also somewhat pronounced for a cecidomyiid (R. J. Gagne, pers. comm.). ${ }^{3}$

Phylomyza sp. near securicornis, length $2.8 \mathrm{~mm}$. A single female was found riding on a Nephila clavipes at the juncture of the abdomen and cephalothorax. This is the only species we encountered that appeared to be phoretic, i.e., attached to a host who is not fed upon. Phoresy is reported in a neotropical Phyllomyza sp. (Robinson and Robinson 1977). Our sighting was made at night.

Neophyllomyza species A, length $1.5 \mathrm{~mm}$. A diurnally active species captured in Marion Co., Fla., on the prey of a Nephila clavipes. The mouthparts are as elongated as those of Paramyia nitens; the rostrum is $1.3 \times$ the height of the head. The single female specimen was 1 of 5 flies on the prey (see below).

Neophyllomyza species B, length $1.8 \mathrm{~mm}$. A species taken from the same prey as species A. Mouthpart development is more conventional. The rostrum is $0.8 \times$ the height of the head. Two females were captured.

\section{Suspected Kleptoparasites}

The following were captured most frequently in traps baited with spider prey. Flies may be kleptoparasites or participants in a number of other symbioses, locating spiders, their eggs or webs through scents released by pre-oral digestion.

Ceratopogonidae: Culicoides bauri, length $1.0 \mathrm{~mm}$. Seven females were taken from spider prey discs, three on intact insects but none on controls. The two previous feeding records of $C$. bauri were from humans, suggesting catholic tastes (see Blanton and Wirth 1979). A considerable number of Ceratopogonidae are carnivores, saprophrages or ectoparasites of insects (Downes 1978; Downes and Smith 1969; Wirth 1956, 1971). Downes and Smith (1969) mention an Atrichopogon sp. feeding on dead insects in spider webs.

Phoridae: Megaselia sp., length 2-3 mm. Seven female specimens of this genus were taken from spider prey-baited discs, none from intact insects or controls. Kleptoparasitism may not be the most

\footnotetext{
${ }^{3}$ In a more benign relationship probably derived from kleptoparasitism, Australian orb-web spiders spread their chelicerae to aid mutualistic milichiids cleaning their mouthparts (McMillan 1975).
} 
attractive interpretation of the data since species of Megaselia are known to both attack spider eggs and oviposit on dead insects (Bristowe 1941; Disney and Evans 1979). Bristowe (1924) found commensal phorids living in the burrows of Brazilian mygalomorphs, where they breed in the remains of the spiders' meals.

\section{Discussion}

Proximity between kleptoparasites and hosts

The results of trapping with spider prey bait show that Didactylomyia longimana, and perhaps other kleptoparasites, locate food by tracking the scents of haemolymph and/or digestive compounds. Flies may remain in the vicinity of a spider after eating, or locate and stay near nonfeeding spiders, to wait for subsequent meals. The above tactics are not mutually excluvive either within a species or the repertoire of a single individual. The "decision" to stay with a preyless spider or to go might depend on the searching ability of the parasite, the danger of travel, and the density of hosts (see Robinson and Robinson 1977). Flying Didactylomyia longimana were always seen coming towards prey from downwind, but "resting" individuals commonly hung on the non-sticky supportive lines of spider webs. Such behavior is common in other Nematocera, cecidomyiids and tipulids, and is apparently a means of escaping stalking predators on foliage (Robinson and Robinson 1976). In a kleptoparasite, the duration of hanging bouts might be influenced by host finding considerations.

Among the flies that wait near spiders, competition to reach choice feeding sites might favor those individuals who maintain the most intimate relationships with their hosts. The degree of intimacy between the symbionts depends on the parasite's ability to overcome the formidable dangers of a gargantuan predator and its entangling web. The kleptoparasitic empidid Microphorus crassipes is a frequent prey of its host (Laurence 1948). Spiders are a major cause of mortality in kleptoparasitic panorpids (Thornhill 1978). We witnessed a Paramyia nitens become trapped in an Argiope aurantia web after being flushed from the prey. McCook (1889) found a similar fly "trussed up near the spot where it had lately fed."

Some symbionts live in webs but escape entrapment (Bristowe 1941; Worth 1967; Davis and Russel 1969; McMillan 1975; Thornhill 1975). Didactylomyia longimanus was occasionally seen 
to safely hang on the viscid spiral lines of Nephila clavipes webs, perhaps by utilizing the comparatively "dry" areas between glue droplets. The Uganda chloropid Anomoeoceros punctulatus stays close to areneids and avoids the web by hovering, even in strong winds, directly beneath the spider (Ismay 1977; chloropids are acalypterates that may be kleptoparasites, parasitoids or both of spiders, Bristowe 1941; Harkness and Ismay 1975; Robinson and Robinson 1977). Perching upon the spider itself seems energetically less expensive. Among Florida kleptoparasites, only Phyllomyza sp. appeared to be phoretic. Phoresy is found in several Old World and neotropical milichiids and chloropids (Bristowe 1931, 1941; Richards 1953; Robinson and Robinson 1977; Ismay 1977). Even on the spider, competition might drive individuals closer to the source of nourishment and could explain the striking concentration of flies on the cephalothorax of a Nephila clavipes illustrated in Robinson and Robinson (1977; note that Anomoeoceros punctulatus hover near the jaws of hosts; see Ismay 1977).

\section{Spatial distribution}

The distribution of milichiids is distinctly clumped. We observed dozens of spiders over a period of several weeks and found only four with milichiid kleptoparasites. Of these, however, ten flies were present in one instance, five in another, and single flies in the other two (see also apparent clumping in Robinson and Robinson 1977; McCook 1889; Bristowe 1931, 1941; Richards 1953). Perhaps some spiders, or their prey, may be more attractive. In most descriptions of milichiid kleptoparasitism, the flies were found feeding on Hymenoptera prey (Clausen 1940; Knab 1915; Bristowe 1931, 1941; Richards 1953; Robinson and Robinson 1977; Ross, pers. comm.). We discovered milichiids on the following prey items: a vespid wasp, an unidentified Hymenoptera, and a pentatomid bug. A preference for Hymenoptera prey would be a curious attribute for an orb weaver associate. Hymenoptera do not appear to consitute a large part of the average spider's diet in our area or in other studies (e.g., $0.4 \%$ by weight for Argiope argentata, Robinson and Robinson 1970). It is possible that an easily tracked substance is released which attracts the flies during the capture or consumption of Hymenoptera. On the other hand the crab spider host Misumena spp. (Thomisidae) frequently preys on bees (Biro 1899; Bristowe 1941). Desmometopa sordida was the kleptoparasite in a number of the 
references cited above. In each case, it is feeding on a honeybee. According to O'Toole (1978), D. sordida is also phoretic on honeybees.

Clumping could also result from a simultaneously emerging brood that locates a host near the site of eclosure. The presence of two species, Neophyllomyza A and B, in the instance where five flies were found on one prey is not supportive of this explanation. Two species of Swedish milichiid kleptoparasites have also been taken from the same prey (Lundstrom 1906 in Knab 1915).

The distribution of the sexes

All of the flies taken on spider prey or in baited traps were female. Nearly all kleptoparasites mentioned in the literature are female as well. Among Diptera, the female usually takes more animal food than the male (Downes 1971) or ingests such food exclusively. Concentrations of females, however, might be expected to attract males. In a number of blood-sucking flies, males are common in the vicinity of hosts (Anderson 1974). The marked female bias may be due to the fact that females remain near the host while males are in transit between sites that might harbor a mate. In scarce, widely distributed species, apparently an accurate description of most spider kleptoparasites, a spider would be more apt to attract a prey item than attract a kleptoparasite. A female kleptoparasite might "confidently" wait for prey at a spider; a male kleptoparasite would do better to visit several spiders to find a mate. Among phoretic kleptoparasites, we have found a single record of a riding male, a milichiid, Desmometopa sordida, sitting with a female on the pronotum of a reduviid bug (Richards 1953). The unique case suggests that mate location can occur on the host.

As flies become more numerous or hosts fewer, the probability of the arrival of new females at a spider increases and it might become more advantageous for males to stay near hosts. Didactylomyia longimana is apparently the most common spider kleptoparasite yet described. While only females are taken on prey, both sexes hang in webs. Males of $D$. longimana are more abundant at these sites than males of web-hanging, nonkleptoparasitic cecidomyiids (see Table 1). No mating was observed but male concentrations in webs suggest that males may intercept mates at feeding sites. An alternative explanation is that female $D$. longimana search for food and so spend less time on webbing than "fasting" non-kleptoparasitic 
Table 1. The sex ratio of Didactylomyia longimana compared to that of 6 species of non-kleptoparasitic cecidomyiids hanging in the same webs, chi-square $=10.25$, $\mathrm{p}<.005$. The difference in sex ratios may be the result of $D$. longimana males waiting near sites likely to attract females. Alternatively, female kleptoparasites may search for food and spend less time in webs than either males of their own species or females of non-kleptoparasitic species.

\begin{tabular}{lccc}
\hline & Male & Female \\
\hline D. longimana & 19 & 10 & \\
Non-kleptoparasites & 14 & & 40 \\
\hline
\end{tabular}

females. It is possible that both contribute to the differences between sex ratios.

The predictable arrival of females might also account for the presence of males at feeding sites in the unusual Greek chloropid Trachysiphonella pori. The fly is closely associated with an ant that is preyed upon by the spider Zodarium fernatum (Zodariidae), which lurks about ant nest entrances at night. $T$. pori is a kleptoparasite of the spider, clinging tenaciously to dead ants even as they are moved about by the spider (Harkness and Ismay 1977). Flies are found only at particular ant nests, and it is possible that they breed in or near these nests (a number of acalypterate flies breed in ant nests, e.g. Moser and Neff 1971). If so, males may wait at nests to inseminate emerging females.

\section{SUMMARY}

A diverse kleptoparasitic fly fauna consumes the prey of spiders in northern Florida. The most abundant of these Diptera is a cecidomyiid, Didactylomyia longimana. Our observations constitute only the second record of a nematoceran kleptoparasite of spiders and document a rare case of protein consumption by an adult gall midge. Four species of milichiid were also captured. One species is phoretic. Two others are notable for the extreme enlargement of their mouthparts. Traps baited with spider prey captured one species of Ceratopogonidae and three species of Phoridae that may also be kleptoparasitic. We argue that intraspecific competition could lead to intimate spatial relations between symbionts and that the mating systems of the flies, as reflected by sex ratios near the spiders, are influenced by the relative abundance of hosts. 


\section{ACKNOWLEDGEMENTS}

Tim Forrest, Jim Lloyd, Pat Sivinski, Bob Sullivan, and Thomas Walker read and improved the manuscript. Warren Prince caught two of the milichiid species and described the circumstances of the capture. Dr. R. J. Gagne gave us timely information and references concerning Cecidomyiidae. Lt. Beckham of the Florida State Dept. of Natural Resources graciously permitted use of the Devil's Millhopper State Geologic Site. Dr. J. A. Downes told us of an important paper and Pat Sivinski translated several articles.

We would like to thank the following taxonomists of the SEAUSDA for their expeditious identifications: Drs. R. J. Gagne, C. W. Sabrosky, W. W. Wirth.

Barbara Hollien professionally prepared the manuscript. Florida Agricultural Experiment Station Journal Series No. 2894.

\section{REFERENCES Cited}

ANDERSON, J. R.

1974. Symposium on reproduction of arthropods of medical and veterinary importance. II. Meeting of the sexes. J. Med. Entomol. 11:7-19.

BIRO, L.

1899. Commensalismus bei Fliegen. Termes. Fuzetek. 22:198-204.

Blanton, F. S., and W. W. Wirth.

1979. Arthropods of Florida and neighboring land areas. Vol. 10: The sand flies (Culicoides) of Florida. Fla. Dept. Ag. Cons. Serv., Gainesville.

Bristowe, W. S.

1924. XXI. Notes on the habits of insects and spiders in Brazil. Trans. Roy. Entomol. Soc. Lond. 475-504.

1931. Notes on the biology of spiders. VII. Flies that triumph over spiders. Ann. Mag. Nat. Hist. 10:471-474.

1941. The comity of spiders, Vol. II. London.

Champion-Jones, R. N.

1937. XXIX. The giant wood spider. J. Bombay Nat. Hist. Soc. 34:425-426.

Davis, R. N., AND M. P. RuSsell.

1969. Commensalism between Ranzovius moerens (Reuter) (Hemiptera: Miridae) and Hololena curta (McCook) (Araneida: Agelenidae). Psyche 76:262-269.

Disney, R. H. L., and R. E. Evans.

1979. Phoridae (Diptera) whose larvae feed on the eggs of spiders (Araneida). Entomol. Mon. Mag. 115:21-22.

Downes, J. A.

1971. The ecology of blood sucking Diptera: An evolutionary perspective. Pages 232-258 in A. M. Fallis (ed.). Ecology and physiology of parasites: A symposium. Toronto Univ. Press. 
1978. Feeding and mating in the insectivorous Ceratopogoninae (Diptera). Mem. Entomol. Soc. Can. No. 104.

Downes, J. A., AND S. M. Smith.

1969. New or little known feeding habits in Empididae (Diptera). Can. Entomol. 101:404-408.

Farquharson, C. O.

1922. Five years observations on the bionomics of Southern Nigerian insects. Trans. Roy. Entomol. Soc. Lond. 54:319-448.

Frost, C. A.

1913. Peculiar habits of small Diptera, Desmometopa latipes Meig. Psyche 20:37.

HARKNESS, R. D., AND J. W. ISMAY.

1975. A new species of Trachysiphonella (Dipt. Chloropidae) from Greece, associated with an ant Cataglyphis bicolor (F.) (Hym. Formicidae). Entomol. Mon. Mag. 111:205-209.

HenNig, W.

1937. Milichiidae et Carnidae. In E. Lindner (ed.). Die Fliegen der palaear tischen Region. Vol. 60a.

ISMAY, J. W.

1977. Anomoeoceros punctulatus (Bekker) (Dipt. Chloropidae) associated with spiders. Entomol. Mon. Mag. 113:248.

JEANNE, R. L.

1972. Social biology of the neotropical wasp Mischocyttarus drewseni. Bull. Mus. Zool. Comp. Harvard 144:63-150.

Kertesez, C. von.

1897. Dipterologisches aus Neu-Guinea. Termes. Fuzetek. 20:611-613.

KNAB, F.

1915. Commensalism in Desmometopa. Proc. Entomol. Soc. Wash. 17:117121.

LAURENCE, B. R.

1948. Observations on Microphorous crassipes MacQuart (Dipt. Empididae). Entomol. Mon. Mag. 84:282-283.

МсCоoK, H. C.

1889. American spiders and their spinning work. Vol. I. Philadelphia.

McMillan, R. P.

1975. Observations on flies of the family Milichiidae cleaning Araneus and Nephila spiders. W. Aust. Nat. 13:96.

MIK, J.

1898. Merkwürdige Beziehungen zwischen Desmometopa m-atrum Meig. aus Europa und Agromyza minutissma V. D. Wulp aus Neu-Guinea. Wiener Emtomol. Zeit. 17:146-151.

Moser, J. C., ANd S. E. NefF.

1971. Pholeomyia comans (Diptera: Millichiidae) an associate of Atta texana: larval anatomy and notes on biology. Z. Ang. Entomol. 69:343-348.

NyffeleR, M., AND G. BENZ.

1980. Kleptoparasitismus von juvenilen Kreuzspinnen und Skorpionsfliegen in den Netzen adulter Spinnen. Rev. suisse Zool. 87(4):907-918. 
O'TOOLE, C.

1978. Pages $157-162$ in A. Stubbs and P. Chandler (eds). A Dipterist's handbook. Anat. Entomol. Soc. Middlesex, U. K.

PeyerimhofF, P. De

1917. Phoresie et commensalisme chez les Desmometopa. Bull. Soc. Entomol. France 1917:215-218.

RICHARDS, O. W.

1953. A communication on commensalism of Desmometopa (Diptera: Milichiidae) with predacious insects and spiders. Proc. Roy. Entomol. Soc. Lond. C.18:55-56.

Robinson, M. H.

1978. Symbioses between insects and spiders: an association between Lepidopteran larvae and the social spider Anelosimus eximius (Araneae: Theridiidae). Psyche 84:225-232.

RoBINSON, M. H., AND B. RoBINSON.

1970. Prey caught by a sample population of the spider Argiope argentata in Panama: a year's census data. Zool. J. Linn. Soc. 149:345-356.

1976. A Tipulid associated with spider webs in New Guinea. Entomol. Mon. Mag. 112:1-3.

1977. Associations between flies and spiders: biocommensalism and dipsoparasitism. Psyche 84:150-157.

Slosson, A. T.

1896. Singular habit of a Cecidomyid. Entomol. News 7:238-239.

Stowe, M. K.

1978. Observations of two nocturnal orbweavers that build specialized webs: Scoloderus cordatus and Wixia ectypa (Araneae: Araneidae). J. Arachnol. 6:141-146.

THORNHILL, R.

1975. Scorpionflies as kleptoparasites of web-building spiders. Nature 258: 709-7111.

1978. Some arthropod predators and parasites of adult scorpionflies (Mecoptera). Environ. Entomol. 7:714-716.

Vollrath, F.

1977. Zur Ökologie und Biologie von kleptoparasitischen Argyrodes elevatus und synoken Argyrodes arten. Dissertation Univ. Freiburg.

1979a. Behavior of the kleptoparasitic spider Argyrodes elevatus (Theridiidae). Anim. Behav. 27:515-521.

1979b. A close relationship between two spiders (Arachnida, Araneinae): Curimagua bayano synecious on a Diplura species. Psyche 85:347-353.

WIRTH, W. W.

1956. New species and records of biting midges ectoparasitic on insects (Diptera, Heleidae). Ann. Entomol. Soc. Amer. 49:356-364.

1971. A review of the "stick-ticks," neotropical biting midges of the Forcipomyia subgenus Microheiea parasitic on walking stick insects (Diptera: Ceratopogonidae). Entomol. News 82:229-245.

WORTH, C. B.

1967. A naturalist in Trinidad. J. B. Lippincott, Co., Philadelphia. Young, A. M.

1971. Foraging for insects by a tropical hummingbird. Condor 73:36-45. 

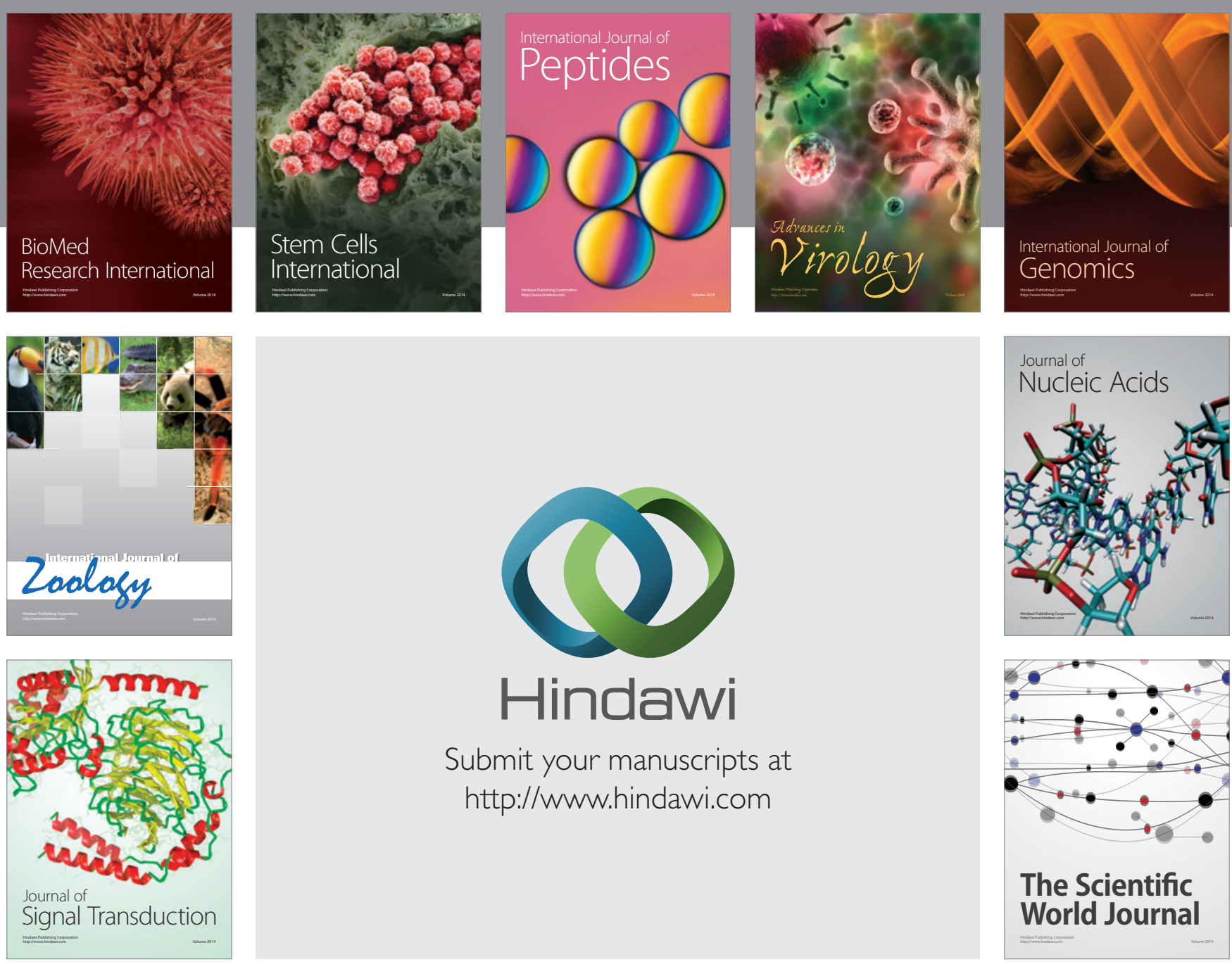

Submit your manuscripts at

http://www.hindawi.com
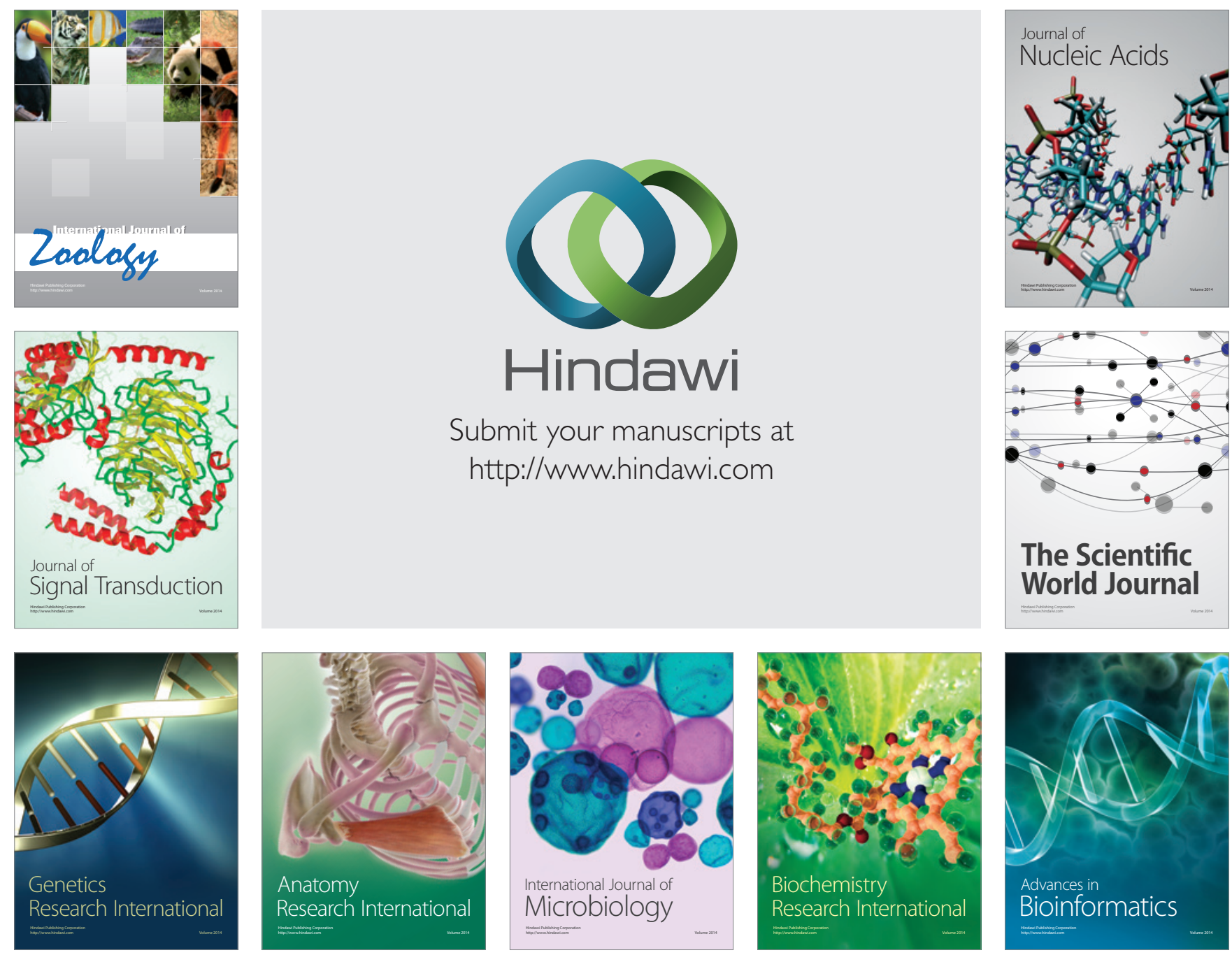

The Scientific World Journal
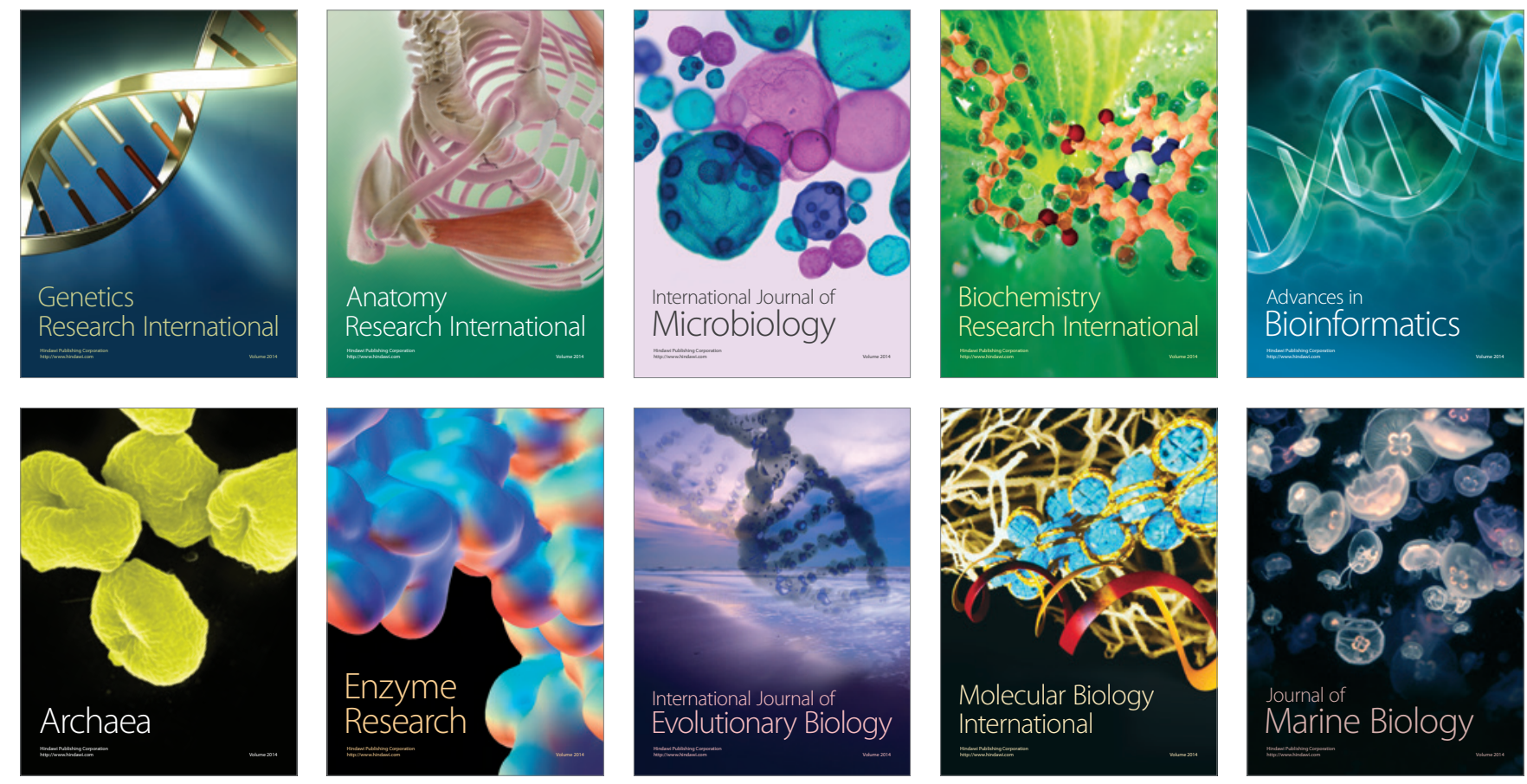